\title{
MICROORGANISMS CONTAMINATING TICKS COLLECTED AT NATURAL RESERVES OR WILD ANIMALS
}

\author{
MICRORGANISMOS CONTAMINANTES DE CARRAPATOS COLETADOS EM \\ RESERVAS NATURAIS OU ANIMAIS SELVAGENS
}

\section{Jamile de Oliveira PASCOAL ${ }^{1}$; Maria Marlene MARTINS ${ }^{2}$; Cristiane Silveira de BRITO³; Matias Pablo Juan SZABÓ ${ }^{4}$}

1. Veterinary Science PhD student at the Federal University of Uberlândia, MG, Brazil. jamileopascoal@ yahoo.com.br; 2. Applied Immunology and Parasitology PhD student at the Federal University of Uberlândia, MG, Brazil; 3. Biology laboratory technician with a $\mathrm{PhD}$ in Applied Microbiology, Immunology and Parasitology. Microbiology Teaching and Research Laboratory from the Federal University of Uberlândia, Uberlândia, MG, Brazil; 4. Associate Professor at the Federal University of Uberlândia. Ixodology Laboratory from the Federal University of Uberlândia, Uberlândia, MG, Brazil.

\begin{abstract}
This work investigated microorganisms responsible for the contamination and death of ticks from natural reserves and wild animals and later kept in the Laboratory of Ixodology in the Veterinary School of the Federal University of Uberlândia. Such investigation aimed prevention of tick death in the laboratory but also search for microorganisms to be used in the biological control of ticks. From four tick samples of Amblyomma genus, the following agents were isolated: Staphylococus sp, Gram positive bacillus, filamentous fungi of the genera Aspergillus and Penicillium, and a yeast identified as Non-albicans Candida and Cryptococcus sp. Even though the source of contamination of these ticks is uncertain, this study displayed the necessity of to better evaluating the spread of pathogens by ticks, as well as those known to be transmitted solely during tick feeding.
\end{abstract}

KEYWORDS: Bacteria. Fungi. Contamination. Ixodidae.

\section{INTRODUCTION}

Ticks are of great relevance to both public and animal health. These parasites are the main vectors of pathogens to domestic animals and are second to mosquitoes in the case of human beings. Besides pathogen transmission, ticks reduce animal production and impacts on animal health by spoliation, skin lesions, and toxicosis (JONGEJAN; UILENBERG, 2004).

Most of the existing information in Brazil is related to ticks from domestic animals whereas a huge knowledge gap occurs in the case of ticks from wild animals. Nonetheless, these arthropods parasitize all terrestrial vertebrates, including birds (SONENSHINE, 2002). In fact, ticks rely on their hosts for mobility. Under this setting, bird ticks might pose a serious threat of disease dissemination if vectors of pathogenic microorganisms (ARZUA et al., 2003).

Research of tick-associated microorganisms fulfills two objectives; detection of infectious agents to human and various animal species as well as those pathogenic to the vector and that might be used for biological control. Biological control of tick vectors is an alternative to currently used acaricides that pollute and their efficacy is decreasing with the selection of resistant parasite populations (SAMISH et al., 2004). Actually, several fungi such as Metarhizium anisopliae and
Beauveria bassiana are pathogenic to ticks. These microorganisms massively colonize tick tissues killing them in a few days (BITTENCOURT et al., 1999; GARCIA et al., 2004).

In nature, microorganisms participate of tick control in the environment during the long off-host periods (SZABÓ et al., 2009). For this reason it is possible to suppose that a few of these microorganisms could be used as new biological control agents against ticks. The aim of this study was to identify microorganisms that allegedly colonized and killed ticks in laboratory after capture in reserves or picked from wild animals. This investigation was necessary to understand high mortality rate of ticks in laboratory and to search for microorganisms that could be used for biological control of these arthropods and detection of infectious agents to human and various animal species.

\section{CONTENT}

All ticks from this study belonged to Amblyomma genus and originated from wildlife. They were taken to the Ixodology Laboratory of the Federal University of Uberlândia and died while maintained in an incubator (ELETROLAB®) in 2008 (Table 1). All ticks were held for at least 15 days in an incubator at $27{ }^{\circ} \mathrm{C}$, and $80 \% \mathrm{RH}$ under $24 \mathrm{~h}$ darkness before examining for microorganisms. 
Cultures of tick microorganisms were prepared as described before (KONEMAN et al., 2001). Four tick samples (Table 1) covered by fungus were placed in one glass tube each with saline solution and kept under refrigeration. Later tubes underwent vortexing and each sample was placed in two different culture mediums for growth of microorganisms according to the manufacturer's instructions. Samples in Sabouraud Dextrose Agar (NEOGEN (B), used for fungus growth, were kept in room temperature for eight days and samples in Agar TSA (Tryptic Soy Agar - BD Difco ${ }^{\text {TM }}$ ), used as nutrient source for microorganisms were incubated at $37^{\circ} \mathrm{C}$ for $48 \mathrm{~h}$. Slide culture was also used for identification of fungus.

Microorganism colonies were identified according to morphological and staining characteristics (Gram stain) and classic microbiologic techniques. Staphylococcus, genus,
Gram- positive bacilli and yeast-form fungi were characterized by morphology. Yeast-form fungi were identified for microscopic features such as germinative tube and CHROMAGAR Candida was used for presumptive characterization of Candida albicans, Candida tropicalis and Candida krusei. Urease production test was used to distinguish Cryptococcus sp. from Candida sp. (KONEMAN et al., 2001).

Staphylococcus sp. and Gram positive bacilli colonies grew in the TSA medium and in one of the samples an urease positive yeast, Cryptococcus sp., grew as well. Aspergillus sp. Penicillium sp. grew in Sabouraud medium. Yeast found in two plaques was urease negative (Candida). CHROMAGAR culture allowed this yeast to be classified as Non-albicans Candida (Table 1).

Table 1. Origin of parasites and contaminant microorganisms of ticks from reserves or wild animals, Uberlândia, MG.

\begin{tabular}{|c|c|c|c|}
\hline Sample & Ticks & Origin & $\begin{array}{l}\text { Contaminant } \\
\text { Microorganisms }\end{array}$ \\
\hline 1 & $\begin{array}{l}2 \text { nymphs } \\
\text { Amblyomma sp. }\end{array}$ & $\begin{array}{l}\text { Larvae captured in Glória Farm of the } \\
\text { Federal University of Uberlândia and } \\
\text { fed on chick. }\end{array}$ & $\begin{array}{l}\text { Aspergillus sp. } \\
\text { Penicillium sp. } \\
\text { Non-albicans Candida } \\
\text { Gram-positive bacilli }\end{array}$ \\
\hline 2 & $\begin{array}{l}6 \text { nymphs } \\
\text { Amblyomma sp. }\end{array}$ & $\begin{array}{l}\text { Cerrado (savannah) from the Clube } \\
\text { Caça e Pesca reserve, Uberlândia, MG. }\end{array}$ & $\begin{array}{l}\text { Aspergillus sp. } \\
\text { Staphylococcus sp. }\end{array}$ \\
\hline 3 & $\begin{array}{l}\text { Nymph } \\
\text { Amblyomma sp. }\end{array}$ & $\begin{array}{l}\text { Giant anteater found within the city of } \\
\text { Frutal, MG. }\end{array}$ & $\begin{array}{l}\text { Aspergillus } \mathrm{sp} . \\
\text { Cryptococcus } \mathrm{sp} . \\
\text { Gram-positive bacilli }\end{array}$ \\
\hline 4 & $\begin{array}{l}\text { Nymph } \\
\text { Amblyomma sp. }\end{array}$ & $\begin{array}{l}\text { Nymph of Bird captured at the Glória } \\
\text { Farm from the Federal University of } \\
\text { Uberlândia and fed on chick. }\end{array}$ & $\begin{array}{l}\text { Aspergillus } \mathrm{sp} . \\
\text { Penicillium } \mathrm{sp} . \\
\text { Non-albicans Candida } \\
\text { Staphylococcus } \mathrm{sp} .\end{array}$ \\
\hline
\end{tabular}
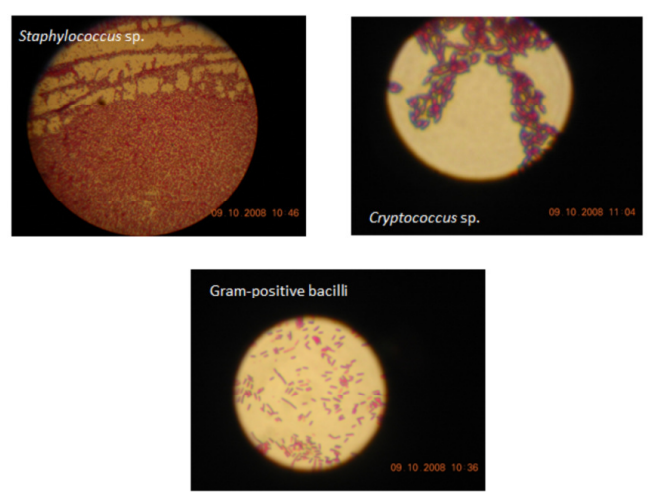

Figure 1. Microorganisms identified in TSA medium.

By this time, it is impossible to determine origin of microorganisms on ticks since this vectors had a
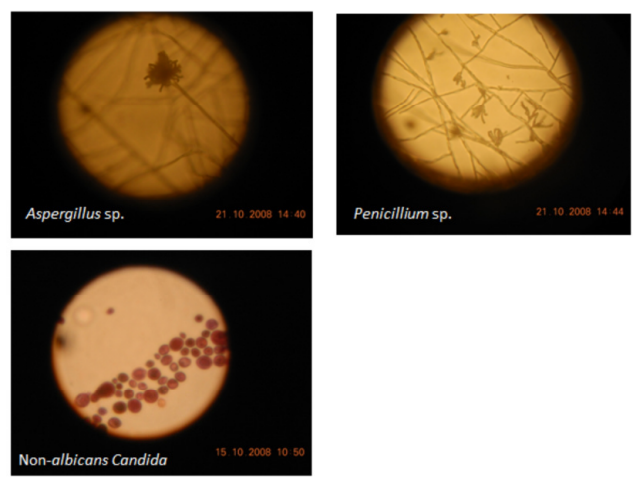

Figure 2. Microorganisms identified in Sabouraud medium.

long way from nature until microorganism isolation and identification. It is worthwhile mentioning that 
ticks from domestic animals were kept in the same incubator but only those from wildlife were covered by fungus. This indicates that origin of the fungus was not the incubator (routinely cleaned). It is also impossible to know if ticks died because of the infection with the detected microorganisms. However, the knowledge of the association of these microorganisms with ticks is, on its own, a relevant observation; it indicates that ticks can carry pathogens, at least mechanically. A second interesting observation relates a possible role in nature by microorganism diversity on ticks. Even though some of them can infect and kill these vectors, others might be related to the inhibition of pathogenic ones. Such situation seems to have occurred in experiments with Amblyomma incisum (SZABÓ et al., 2009). These authors observed that if maintained in incubators at highly humid conditions, similar to the ones found in their natural settings, engorged female ticks were soon fungus covered and died without ovipositing. However, female ticks from the same cohort kept in metal cages in humid forests, oviposited normally. Several influences should be considered in this case, but it can be speculated that fungus infection was controlled by microbiota from the forest.

Bacteria found in this work were all Grampositive and ubiquitous in nature. They are found on the soil, air, water or as commensals on animal and human skin. These bacteria have both pathogenic and no-pathogenic strains and infection and transmission vary according to the strain (CARTER, 1988; SONGER \& POST, 2005).

Aspergillus genus was the most prevalent among the isolated yeast-form fungi, followed by Penicillium, both saprophytic. In a similar work, Monteiro et al. (2003), found mainly Penicillium followed by Aspergillus, and four other yeast-form fungi on ticks undergoing natural infection. These authors highlighted that medium used for culture as well as competition among fungus may have inhibited growth of entomopathogenic fungus, as they grow slower than those saprophytic. Such might have happened in our work as well.

According to Passoni (1999), Cryptococcus spp. can be found in the soil, decomposing wood and bird excreta, especially of pigeons. Pigeons are mechanic vectors and their excreta is a natural substrate for the fungus. These birds by braking and scraping wood for nests seems to create ideal conditions for the survival of the pathogenic Cryptococcus neoformans.

Pascoal et al. (2013) observed on survey for ticks on birds that Amblyomma nodosum was a major tick species on passerine birds at a Cerrado reserve. While nymphs parasitize birds, adults of this tick species are routinely found on anteaters (Myrmecophaga tridactyla, Tamandua tetradactyla) (MARTINS et al., 2004). In this context, a few bird species pose a potential problem for tick-associated pathogen dissemination thanks to their high capacity of moving. An especial attention should be given to sinantropic birds such as pigeons, sparrows and others. In the case of the Cryptococcus sp. recovered from an A. nodosum from an anteater, fungus could have infected tick in nature (Cerrado). On the other way round, infection could have occurred in the Veterinary Hospital where the anteater remained for a few days close to several other animals from various origins.

Most of the observations about microorganisms pathogenic to ticks are restricted to entomopathogenic fungus such as Metarhizium anisopliae and Beauveria bassiana (GARCIA et al., 2008; BITTENCOURT et al., 1999; PRETTE et al., 2005). Much less is known about other fungus species on ticks, particularly of the Amblyomma genus.

Agents such as Aspergillus, Candida, Cryptococcus and zygomicet species were once considered laboratory contaminants and clinically irrelevant. These species, however, are by now recognized as pathogens associated to ailments such as endocarditis, lung infections, keratitis and others, particularly in immunosuppressed patients (ANVISA, 2004).

Thus bacterial (Staphylococcus sp. and Gram- positive) and fungi and yeast (Aspergillus sp., Penicillium sp., Candida sp. e Cryptococcus sp.) found herein, irrespective of contamination source, whether in nature or later in human settings (veterinary hospital, laboratory), displays the capacity of ticks disseminating pathogens not only during hematophagy but also of those carried on tick surface.

\section{ACKNOWLEDGEMENTS}

We are indebted to Dr. Paulo Gontijo Pinto Filho, head of the Microbiology Teaching and Research Laboratory from the Federal University of Uberlândia, for permission to use the Laboratory and collaborating with material. This research was supported by Conselho Nacional de Desenvolvimento Científico e Tecnológico - CNPq (scholarship to J.O., Pascoal and Academic Career Research Fellowship to M.P.J. Szabó). 
RESUMO: Neste trabalho foram investigados microrganismos responsáveis pela colonização e morte de carrapatos provenientes de reservas naturais ou animais selvagens e mantidos posteriormente no Laboratório de Ixodologia da Faculdade de Medicina Veterinária da Universidade Federal de Uberlândia. Esta investigação se fez necessária para tentar prevenir mortalidade de carrapatos no laboratório, mas também para contribuir com a busca por microrganismos que poderiam ser utilizados no controle biológico do ácaro. Foram isolados de cinco amostras de carrapatos do gênero Amblyomma os seguintes microrganismos: Staphylococus sp, bacilos Gram positivos, fungos filamentosos dos gêneros Aspergillus e Penicillium, além de leveduras identificadas como Candida não-albicans e Cryptococcus sp. Mesmo que a origem da contaminação dos carrapatos com estes microrganismos seja incerta este trabalho indica a necessidade de se avaliar melhor a difusão de outros patógenos por carrapatos, além daqueles transmitidos com a hematofagia.

PALAVRAS-CHAVE: Bactérias. Fungos. Contaminação. Ixodídeos.

\section{REFERENCES}

ANVISA-AGÊNCIA NACIONAL DE VIGILÂNCIA SANITÁRIA. Detecção e Identificação dos Fungos de Importância Médica, Módulo VII. 2004. On-line. Disponível na Internet: http://www.anvisa.gov.br/servicosaude/microbiologia/mod_7_2004.pdf. Acesso em: 10 nov. 2008.

ARZUA, M.; SILVA, M. A. N.; K. M. FAMADAS; L. BEATI, D.M.; BARROS-BATTESTI. Amblyomma aureolatum and Ixodes auritulus (Acari: Ixodidae) on birds in southern Brazil, with notes on their ecology. Experimental and Applied Acarology, Netherlands, v. 31, n. 3-4, p. 283-296, 2003.

BITTENCOURT, V. R. E. P.; MASCARENHAS, A. G.; FACCINI, J. L. H. Mecanismo de infecção do fungo Metarhizium Anisopliae no carrapato Boophilus Microplus em condições experimentais. Ciência Rural, Santa Maria, v. 29, n. 2, p. 351-354, 1999.

CARTER, G. R. Fundamentos de Bacteriologia e Micologia Veterinária. $1^{\text {a }}$ ed. São Paulo: Roca, 1988. 249p.

GARCIA, M. V.; MONTEIRO, A. C.; SZABÓ, M. P. J. Colonização e lesão em fêmeas ingurgitadas do carrapato Rhipicephalus sanguineus causadas pelo fungo Metarhizium anisopliae. Ciência Rural, Santa Maria, v. 34, n. 5, p. 1513-1518, Set/Out, 2004.

GARCIA, M. V.; MONTEIRO, A. C.; SZABÓ, M. P. J.; PRETTE, N. Eventos externos e internos da infecção de larvas e ninfas de Rhipicephalus sanguineus por Metarhizium anisopliae. Arquivo Brasileiro de Medicina Veterinária e Zootecnia, Belo Horizonte, v. 60, n. 4, p. 855-863, 2008.

JONGEJAn, F; UILENBERG, G. The global importance of ticks. Parasitology, London, v. 129, Supplement S1, p. S3-S14, 2004.

KONEMAN, E. W.; ALLEN, S. D.; JANDA, W. M. SCHRECKENBERGER, P. C.; WINN, W. C. J. Diagnóstico Microbiológico: Texto e Atlas Colorido. Rio de Janeiro: MEDSI. 5 ed. p. 434, 2001.

MARTINS, J. R.; MEDRI, I. M.; OLIVEIRA, C. M.; GUGLIELMONE, A. Ocorrência de carrapatos em tamanduá-bandeira (Myrmecophaga tridactyla) e tamanduá-mirim (Tamanduá tetradactyla) na região do pantanal sul mato-grossense, Brasil. Ciência Rural, Santa Maria, v. 34, n. 1, p. 293-295, 2004.

MONTEIRO, S. G.; MATIMOTO, L. R.; SILVEIRA, F. S.; LEAL, A. M. Isolamento de fungos em carrapatos ixodídeos naturalmente infectados. Revista da Faculdade de Zootecnia Veterinária e Agronomia, Uruguaiana, v. 10, n. 1, p. $65-71,2003$. 
PASCOAL, J. O. ; AMORIM, M. P.; OLEGARIO, M. M. M.; MELO, C.; SILVA JUNIOR, E. L.; OGRZEWALSKA, M.; LABRUNA, M. B.; SZABO, M. P. J. . Ticks on birds in a savanna (Cerrado) reserve on the outskirts of Uberlândia, Minas Gerais, Brazil. Revista Brasileira de Parasitologia Veterinária, Jaboticabal, v. 22, n. 1, p. 46-52, 2013.

PASSONI L. F. C. Wood, animals and human being as reservoirs for human Cryptococcus neoformans infection. Revista Iberoamericana de Micologia, Bilbao, v. 16, p. 77-81, 1999.

PRETTE, N.; MONTEIRO, A. C.; GARCIA, M. V.; SOARES, V. E. Patogenicidade de isolados de Beauveria bassiana para ovos, larvas e ninfas ingurgitadas de Rhipicephalus sanguineus. Ciência Rural, Santa Maria, v. 35, n. 4, Jul/Ago, p. 855-861, 2005.

SAMISH, M.; GINSBERG, H.; GLAZER, I. Biological control of ticks. Parasitology, London, v. 129: S389S403, 2004.

SONENSHINE, D. E.; LANE, R. S.; NICHOLSON, W. L. TICKS (Ixodida). In: MEDICAL AND VETERINARY ENTOMOLOGY. USA: ELSEVIER SCIENCE, 2002. chapter. 24, p. 517-558.

SONGER, J. G.; POST, K. W. Veterinary Microbiology: Bacterial and fungal agents of animal disease. Philadelphia: Elsevier Saunders, 2005. 434p.

SZABÓ, M. P. J.; PEREIRA, L. F.; CASTRO, M. B.; GARCIA, M. V.; SANCHES, G. S.; LABRUNA, M. B. Biology and life cycle of Amblyomma incisum (Acari: Ixodidae). Experimental and Applied Acarology, Netherlands, v. 48, n. 3, p. 263-271, 2009. 